\section{BEING MORAL ISN'T QUITE}

\section{ENOUGH:}

\section{The Role of Nonmoral Virtues in}

\section{Moral Sainthood}

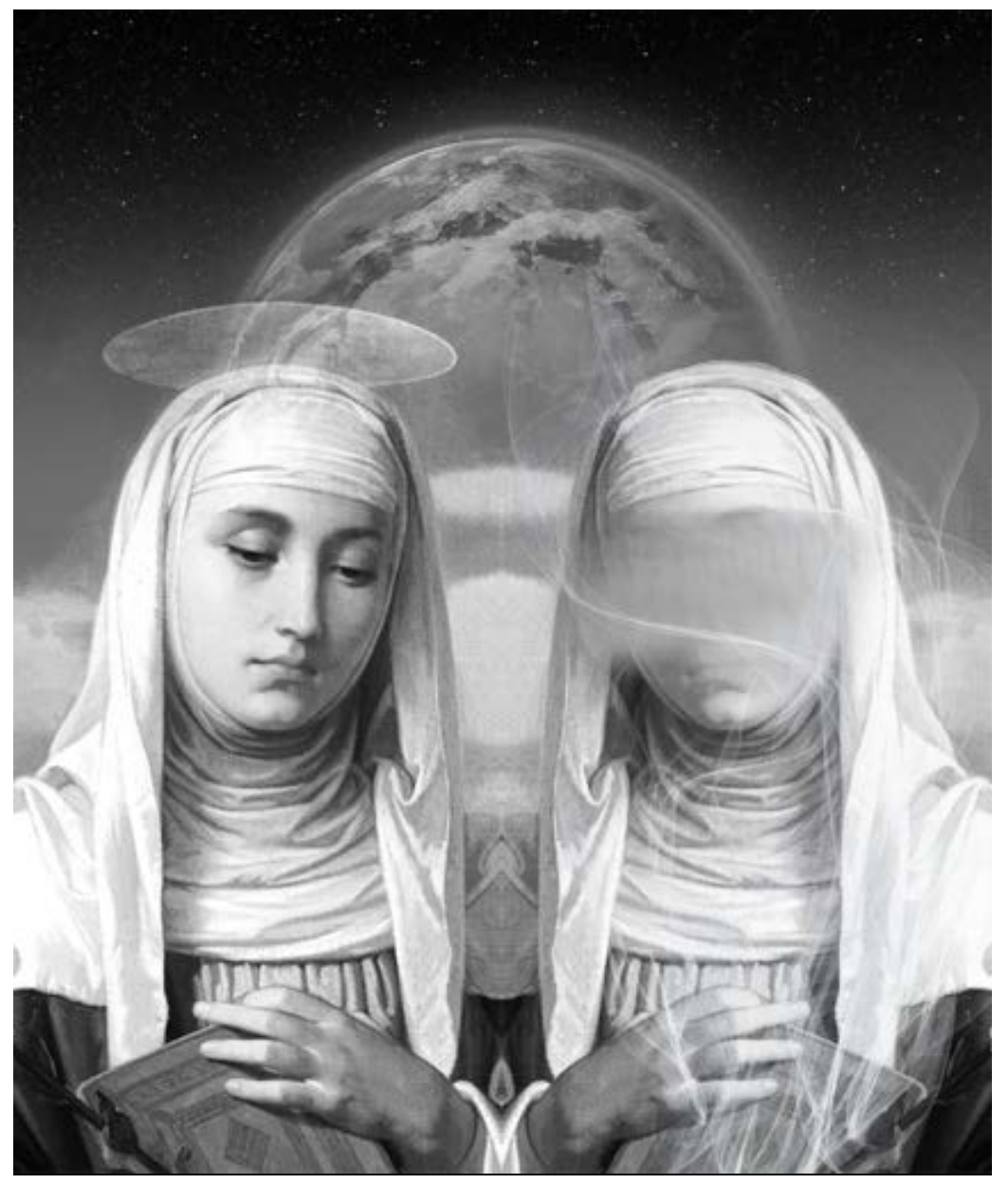

SEYEONG HANLIM

\section{ABSTRACT}

Attempts to define morality or stress its importance are the center of ethical debates that aim to provide guidance for human life. Deviating from this goal, Susan Wolf shines a light on the significance of "nonmoral virtues" by discussing how a moral saint's life, too immersed in morality, could be lacking in other spheres. She states that a moral saint's life would be unattractive or dull, as one is not able to value or pursue nonmoral activities such as the arts or cooking due to one's commitments under moral sainthood. I challenge this argument, which belittles moral sainthood in an attempt to give more credit to nonmoral qualities in life, by arguing that nonmoral virtues could be necessary and valuable for a moral saint in carrying out her duties. 


\section{INTRODUCTION}

In "Moral Saints," Susan Wolf explores the extent to which human lives should be moral by investigating the qualities abundant or lacking in moral saints: those that are considered the ultimate role-models of morality. She defines a moral saint as someone whose every action is maximally moral and lives solely to devote themselves to the welfare of others. ${ }^{1}$ Although Wolf acknowledges the prevalent notion that "one ought to be as morally good as possible," she argues that moral sainthood does not allow room for personal well-being. ${ }^{2}$ Wolf then identifies qualities that are valuable, yet do not have a moral connotation. These are "nonmoral virtues," which one can achieve through pursuing nonmoral interests, skills, or activities such as cultivating one's talents in art, music, or cooking. Wolf elucidates that moral saints lack nonmoral excellence because they do not have time for personal projects, as moral sainthood requires the sole devotion of one's life to society's welfare. Hence, moral saints are "too good for [their] own well-being." ${ }^{3}$ Wolf then considers examples of moral saints whose devotion to moral perfection prevents them from pursuing nonmoral excellence. One example is the utilitarian Loving Saint, who strives to improve the welfare of others out of genuine love for humanity. Wolf explains that a Loving Saint's commitment to utilitarianism gives her "one thought too many" to be able to pursue nonmoral virtues with the correct motivations. ${ }^{4}$ Therefore, Wolf argues that moral sainthood is not a desirable form of human life as it lacks nonmoral excellence. I think that Wolf's account is inaccurate regarding the role of nonmoral virtues in moral sainthood, particularly in that of a utilitarian Loving Saint. I believe that a moral saint can value and pursue moral and nonmoral virtues simultaneously; this is possible because nonmoral excellences are attached to the fundamental qualities of successful moral sainthood.

In section II, I argue that moral saints end up possessing nonmoral virtues in their attempts to achieve moral ends. I follow up this argument with a potential objection that a moral saint's possession of nonmoral qualities might be coincidental; as a result, one might worry that she pursues these excellences in the wrong way. ${ }^{5} \mathrm{Next}$, I point

1 Susan Wolf, "Moral Saints," The Journal of Philosophy 79, no. 8 (1982): 419$20,10.2307 / 2026228.2$.

2 Wolf, "Moral Saints," 419.

3 Wolf, "Moral Saints," 421-22.

4 Bernard Williams, "Persons, Character and Morality," in Moral Luck: Philosophical Papers 1973-1980, ed. Bernard Williams (Cambridge: Cambridge University Press, 1981), 18; quoted in Wolf, "Moral Saints," 430.

$5 \mathrm{She} / \mathrm{her} /$ hers pronouns are used for the author's reference to the Moral/ Loving Saint in this paper. out that a utilitarian Loving Saint, in particular, would value nonmoral interests as a part of her own flourishing as she understands how they are crucial to humankind's flourishing. I then address the concern that the Loving Saint's ability to see values of nonmoral practices in others might not extend to herself. Introducing section IV, I consider the counterargument that even if a Loving Saint values nonmoral interests correctly, her appreciation might be shallow, as she will always prioritize morality. I claim that even if the Loving Saint might give up nonmoral interests when they conflict with her moral duties, this fact does not weaken her attachment to the nonmoral virtues. I suggest that she is only valuing nonmoral things from both moral and nonmoral perspectives, which can be intrinsically consistent with one's moral sainthood. I conclude this paper with a consideration that nonmoral and moral virtues might be interchangeable.

\section{CAN MORAL SAINTHOOD REQUIRE NONMORAL EXCELLENCE?}

Wolf states that,"A moral saint will have to be very, very nice ... as a result, he will have to be dull-witted or humorless or bland." 6 This owes to the fact that moral saints are unduly dominated by the desire to achieve moral perfection, which subsumes or demotes their other desires and requires them to negate the pursuit of nonmoral projects. According to Wolf, these traits make moral saints unattractive or undesirable, because they lack nonmoral virtues developed through genuine appreciation of nonmoral interests. However, Wolf does not consider the possibility that nonmoral virtues might also be attainable through moral activities or interests. Achieving moral perfection requires tremendous effort, which as a result, can cultivate a combination of nonmoral virtues such as rationality, intelligence, persistence, courage, or humor in a moral saint. For example, a moral saint's duties that Wolf describes as "feeding the hungry or healing the sick or raising money for Oxfam" cannot be done by someone who lacks nonmoral virtues. ${ }^{8}$ One needs to be persistent enough to communicate with a starving child who refuses to take medicine, rational and intelligent enough to take care of a dying elder who gets violent out of pain, witty and personable enough to persuade donors or lead an auction for charity, and passionate and courageous enough to persist in moral sainthood while facing the burdens of accompanying duties. What is required of one to become a moral saint includes nonmoral strengths and virtues and pursuing morality does not inhibit

6 Wolf, "Moral Saints," 422

7 Wolf, "Moral Saints," 424

8 Wolf, "Moral Saints," 421. 
one from enriching such human qualities, but rather pushes one to develop them. In sum, moral sainthood mandates efforts and skills to successfully perform moral activities that capture what Wolf views as valuable in nonmoral excellence.

Following this sense, a philosophical concept that might signal the essentiality of nonmoral qualities in moral sainthood is the idea of phronēsis or practical wisdom. An Aristotelian-inspired concept, phronēsis means, "a true and practical state involving reason, concerned with what is good and bad for a human being." the knowledge that enables its possessor to "reason correctly about practical matters" to do what is right in any circumstance, ${ }^{10}$ and only those that are morally excellent can possess this ability through life experience. ${ }^{11}$ For instance, if a moral saint's duties include directing a moral organization, she can utilize her practical wisdom in assigning the appropriate amount and type of tasks to the right kind of workers so that the organization functions well for its purpose. Since phronēsis is tied to the ability to make correct decisions involving morality in this case, its nonmoral value might not be evident. However, someone who is cunning or wicked can also possess the practical knowledge involved in phronēsis to commit evil. ${ }^{12}$ Therefore, this general ability to make good choices concerning practical matters to the extent to which that could be applied in nonmoral contexts seems to depict a nonmoral quality. In other words, phronēsis is not necessarily moral, but one cannot become a successful moral saint without it. As practical wisdom is an essential element in moral sainthood, this makes a case that a moral saint would have to develop a quality that we might classify as nonmoral and is therefore perfecting certain nonmoral abilities in pursuing a moral life.

With regard to the argument concerning the role of nonmoral virtues in moral sainthood, Wolf acknowledged that aspirations to moral sainthood can give one a reason to work hard to develop nonmoral virtues such as courage..$^{13}$ While she noted that one might not be liable to be successful in developing certain nonmoral virtues such as wit and charm for moral reasons, she claimed that the perspective of a moral saint can certainly make one appreciate the instrumental value of

9 Aristotle, Nicomachean Ethics, trans. Roger Crisp (Cambridge: Cambridge University Press, 2000), 107.

10 Rosalind Hursthouse, On Virtue Ethics (Oxford: Oxford University Press, 1999), 12.

11 Gideon Rosen et al., "Virtue Ethics," in The Norton Introduction to

Philosophy, 2nd ed. (New York: W.W. Norton \& Company, 2018), 824; 828.

12 Rosen et al., "Virtue Ethics," 829.

13 Susan Wolf, email message to author, October 30, 2020. these qualities in achieving moral ends. ${ }^{14}$ Here, Wolf highlights how a moral saint's appreciation of such human qualities comes from a moral perspective. Even if the moral saint can attain nonmoral excellence while pursuing moral perfection, she is not thereby treating nonmoral qualities with the correct motivations. In fact, when asked "whether the things that we find appealing about the nonmoral excellences might be conceived of in such a way that it is purely formal so that those abilities might manifest themselves in the moral saint," Wolf answered that, "there's an incompatibility between moral sainthood, and what I find most attractive in these (nonmoral) ideals that is not just about the skills or activities that they engage with but about their motivations and relationship to these activities." ${ }^{15}$

In short, Wolf is saying that what we value about nonmoral virtues is something more than the formal traits describable under the very general heading that manifests different sets of nonmoral human skills. This leads to a fundamental concern that even if moral saints are capable of attaining nonmoral excellence in practice, they are not doing so with the correct motivations, as they develop these qualities accidentally or supplementally while achieving their moral ends rather than directly out of passion with no regards to moral contexts. My reply in the next section offers a different view to this discussion.

\section{CAN MORAL SAINTS APPRECIATE NONMORAL PRACTICES?}

Wolf denotes that, "for a moral saint, the existence of these (nonmoral) interests or skills can be given at best the status of happy accidents." ${ }^{16}$ Nevertheless, it does not occur to me that moral saints would consider nonmoral interests to be valuable only within their contribution to morality and dismiss them when they do not. To expand on this point, I will focus on the specific example of Loving Saints and how they would be able to value nonmoral interests "for their own sakes as distinct, independent aspects of the realization of human good." 17 Loving Saints can appreciate nonmoral activities outside of the limited circumstances of these values aligning with their moral missions by chance. This is because Loving Saints are genuinely concerned about the flourishing of other humans, and thus, the flourishing of humankind in general, and nonmoral practices are the fundamental attributes of life that are crucial to an individual or

14 Wolf, email message to author.

15 Susan Wolf, (special guest at lecture by John McHugh, Denison University, Granville, OH, September 17, 2020).

16 Wolf, "Moral Saints," 425

17 Wolf, "Moral Saints," 425 
humankind's well-being. A Loving Saint pursues morality out of love, as she is nice, sacrifices herself to put others' happiness first, and derives happiness from doing so. ${ }^{18}$ To pursue maximum happiness for the whole population, she will be attentive and interested in others' lives and welfare. Then, she will observe how nonmoral interests are meaningful in a way that is essential to human lives. For instance, by observing someone who devotes thousands of hours into the somewhat bizarre act of trying to control a ball with two feet or someone who will never trade a childhood art piece even for a million dollars, a Loving Saint will come to an understanding that there are things in life that people unconditionally love and value. While promoting others' welfare, a Loving Saint will learn how some activities bring meaning to others' lives and that such qualities do not always have to do with morality. When she sees that nonmoral activities or interests are crucial in human life, she will come to recognize their worth outside of their contribution to morality or overall happiness. It is hard to believe that a Loving Saint's attitude toward nonmoral practices would remain superficial after the realization of their essentiality for human wellbeing. Nonetheless, one can worry that even if a Loving Saint can see the true values of nonmoral interests or activities in other people, she might still be unable to value them for herself. But once a Loving Saint can value nonmoral practices in others, it would be an artificial stretch to assume that she will not thereby value them in herself as well. A Loving Saint's goal in life is to maximize overall happiness, which includes helping others cultivate nonmoral qualities. As a product of her moral efforts in achieving moral perfection, she also cultivates nonmoral excellence within herself, as shown in section II. Given these reasons, if a Loving Saint is already committed to the understanding that it is good for others to pursue a nonmoral project, it would be natural for her to think that for herself as well.

\section{IS THERE A BETTER WAY TO VALUE NONMORAL PRACTICES?}

Wolf agrees that a Loving Saint could, for instance, recognize that others love art for its own sake, and thus, support herself in her efforts to appreciate art if there is nothing more morally valuable to do with her resources. ${ }^{19}$ Wolf implied that if a Loving Saint saw the beauty in a work of art, while doing so, she would unavoidably value it for its own sake. The problem is that, in a certain hypothetical situation, the saint might face a tension between her moral sainthood requiring her to donate to a food bank for maximal general happiness and her genuine

18 Wolf, "Moral Saints," 420

19 Wolf, email message to author. appreciation of nonmoral interests making her want to spend that money to go to a museum to enjoy art for its own sake. While there are people who love art so much that sometimes they make the latter choice, a Loving Saint will be inclined to do what is strictly moral. This means that while a Loving Saint appreciates nonmoral virtues, such appreciation is not free of saintly moral duties or concerns. Wolf explained that in this case, the Loving Saint appreciates art in the right way but does so weakly; she truly loves art but gives it up at the drop of a moral hat. ${ }^{20}$ To introduce Wolf s idea as a formal objection, one might contend that a Loving Saint's appreciation of nonmoral values remains weak even after the realization that nonmoral interests are crucial to human well-being. This is because a Loving Saint will always be willing to exchange her enjoyment of nonmoral activities for other things that produce a greater amount of general happiness. ${ }^{21}$ I respond that there is no reason to think that a moral saint's willingness to give up nonmoral activities in the face of a moral demand indicates her shallowness of attachment to the former. As shown in sections II and III, a moral saint develops nonmoral virtues as a necessary journey to successful moral sainthood, and she also sees the true value of nonmoral activities outside of moral contexts. These qualities remain in her even if she has to prioritize moral duties, and questioning her depth of commitment to nonmoral values in these instances of conflict seems to be a different question.

On the other hand, a plausible counterpoint I see here is that the Loving Saint's consideration for her moral duties in giving up nonmoral activities signifies that her engagement in nonmoral interests will always involve moral perspectives, which might indicate a wrong approach to nonmoral values. However, what I see going on here is not the Loving Saint valuing nonmoral interests less than moral ones as a result of her moral concerns, but her valuing nonmoral things from both moral and nonmoral perspectives. In "Persons, Character and Morality," Bernard Williams discusses Charles Fried's example of a man who takes both moral permissibility and personal relationship into account in his decision to save his wife's life over his friend's, given that the two people are in an equal situation of danger. ${ }^{22}$ Williams responds by saying, "But this construction provides the agent with one thought too many: it might have been hoped by some (for instance, by his wife) that his motivating thought, fully spelled out, would be the thought that it was his wife, not that it was his wife and that in situations of this

20 Wolf, email message to author

21 Wolf, "Moral Saints," 429-30.

22 Charles Fried, "The Value of Life," Harvard Law Review 82, no. 7 (1969): $1432-33,10.2307 / 1339754$ 
kind it is permissible to save one's wife." ${ }^{23}$ Williams assumes that if a man chooses to save his wife, the optimal reason to do so is that she was his loved one, not because it was his moral duty. He asserts that if the man starts to think about the moral permissibility in this situation, such moral concern indicates that he is now having "one thought too many." ${ }^{24}$ I agree with the view that it is wrong for the man to save his wife solely for moral reasons, but I do not find it an issue to take into account both nonmoral interests (his love toward the wife) and the moral permissibility in making such a decision. For instance, after the man rescues his wife, he might put his daily duties or activities aside to visit his wife at the hospital, and there might be two reasons behind doing so: one is he loves his wife, and the other is it is morally right to visit his wife. I do not find a reason for the man's moral reflection to bring "one thought too many" for him as the fact that his decision involved moral considerations does not diminish his nonmoral interest, or in this case, the love he has for his wife. These are simply two different spheres of consideration and the fact that the man's conduct involved both nonmoral and moral interests does not signify that he is treating the other virtue shallowly. I believe that there is nothing intrinsically inconsistent with the Loving Saint's moral sainthood about valuing nonmoral things both morally and nonmorally at the same time. For example, when a Loving Saint engages in developing musical talents, she might be doing so to increase overall utility in the world to achieve her moral ends, but she may also value and appreciate such nonmoral activities outside of utilitarian moral contexts. This does not signify that the Loving Saint is lightly treating the nonmoral project but regards it as valuable, both morally and nonmorally, which is possible, if not good. It is not misguided for a Loving Saint to value nonmoral things from both moral and nonmoral perspectives, and it might be an overstatement to say someone is weakly attached to a nonmoral project if there is a slightest moral consideration involved in doing so.

\section{FURTHER DISCUSSION: ARE MORAL AND NONMORAL QUALITIES CONNECTED?}

So far, I have shown that moral saints cannot perform their moral duties without nonmoral virtues and will develop such qualities to successfully meet their moral ends. Furthermore, a Loving Saint will be able to value nonmoral practices for their own sake as she understands, through observation, that they are essential to others' and humankind's flourishing. To the worry that a Loving Saint's ability to see the true value of nonmoral practices in others does not mean that

23 Williams, "Persons, Character and Morality," 17-18.

24 Williams, "Persons, Character and Morality," 17-18. she can do so in herself, I respond that the extension of a Loving Saint's attitude toward other people is a product of her care for them, and their flourishing can be built in for herself as well. In response to the other concern that moral saints value nonmoral practice in a shallow manner-as they might ultimately prioritize morality - I suggest that a moral saint is merely valuing nonmoral qualities from both nonmoral and moral perspectives, which is consistent with moral sainthood. My claim in this essay has been that both moral and nonmoral qualities are essential for moral sainthood, as a Loving Saint needs to cultivate nonmoral excellence to attain moral perfection, while she values the nonmoral interests the right way.

I would like to end by exploring the possibility that nonmoral and moral qualities are intertwined. Wolf argues that moral saints can only cultivate nonmoral qualities by accident while pursuing their moral ends. ${ }^{25}$ The fact that the pursuit of a moral quality may naturally lead to an acquisition of a nonmoral quality suggests that these two aspects are intertwined, as one might entail the other. This can be further demonstrated by Wolf's examples of what constitutes cultural ideals and my argument of what moral sainthood requires of moral saints. Wolf implies that some degree of morality is a necessary condition of personal excellence when she gives examples of people who are not moral saints but are cultural ideals, as she mentions, "there is certainly nothing immoral about the ideal characters or traits." 26 What this suggests is that there is a minimal bar of moral permissibility that one has to cross in order for the life dedicated to nonmoral qualities to be acceptable. Similarly, moral saints must have some virtues that, strictly speaking, are nonmoral to achieve their moral ends. For instance, there are figures who seem to be maximally moral but are lacking in practical or nonmoral abilities which get in their way of attaining moral perfection. Nonmoral qualities are indispensable to moral sainthood as one cannot pursue the task of caring for others' welfare without a genuine understanding or acquisition of such qualities.

Engaging with "Moral Saints" and Wolf's personal insight, I understood that her ultimate conclusion is not that life dedicated to morality is unattractive, but nonmoral virtues are just as valuable as moral ones. Nonetheless, Wolf might have overstated the potential criticisms of the moral saint in the process of making her argument that life dedicated to nonmoral ideals is defensible. As nonmoral and moral spheres are connected, I believe that it would be possible to emphasize the pursuit of nonmoral qualities without necessarily criticizing or undermining the life dedicated to moral sainthood as barren or undesirable.

25 Wolf, "Moral Saints," 425

26 Wolf, "Moral Saints," 422 


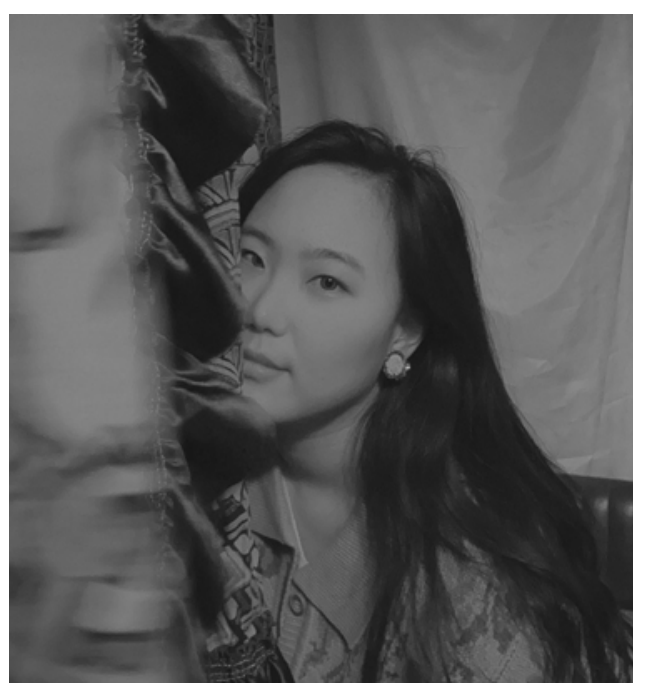

Seyeong Hanlim is a sophomore at

Denison University in Granville, Ohio,

studying politics, philosophy, and music

performance. Her philosophical interests

include feminist, legal, and political

philosophy as well as debates of afterlife

and rebirth. She thanks professors John

McHugh and Susan Wolf, Ms. Kaly Thayer,

and Isabella Lundy for inspiration and

feedback. 